\title{
Chitinase Activity from Candida albicans and its Inhibition by Allosamidin
}

\author{
By KEITH DICKINSON, VALERIE KEER, \\ CHRISTOPHER A. HITCHCOCK AND DAVID J. ADAMS* \\ Department of Microbiology, University of Leeds, Leeds LS2 9JT, UK
}

(Received 5 October 1988; revised 3 January 1989; accepted 20 January 1989)

\begin{abstract}
Candida albicans chitinase isolated using the Dyno-Mill disruption technique was characterized using an improved radiometric assay procedure. The enzyme had apparent temperature and $\mathrm{pH}$ optima of $45^{\circ} \mathrm{C}$ and 6.5 , respectively. The preparation yielded an apparent $K_{\mathrm{m}}$ of $3.9 \mathrm{mg}$ chitin $\mathrm{ml}^{-1}$ [17.6 mM- $N$-acetylglucosamine (GlcNAc) equivalents] and $V$ of $2.3 \mathrm{nmol}$ GlcNAc formed $\mathrm{min}^{-1}(\mathrm{mg} \text { protein })^{-1}$. The potential of the streptomycete antibiotic allosamidin as an antifungal agent is discussed in view of its dose-dependent inhibition of $C$. albicans chitinase activity $\left(\mathrm{IC}_{50}=0.3 \mu \mathrm{M}\right)$. Allosamidin was a potent competitive inhibitor of enzyme activity $\left(K_{\mathrm{i}}=0.23 \mu \mathrm{M}\right)$.
\end{abstract}

\section{INTRODUCTION}

Chitin, a (1 $\rightarrow 4)-\beta$ polymer of $N$-acetylglucosamine (GlcNAc) is a major structural component of most fungal cell walls (Gooday \& Trinci, 1980). The enzyme chitin synthase (EC 2.4.1.16) catalyses the production of this macromolecule by polymerization of GlcNAc from the activated precursor UDP- $N$-acetylglucosamine. There is now compelling evidence that chitin synthase plays a fundamental role in morphogenesis (Cabib, 1987; Silverman et al., 1988). A morphogenetic role has also been proposed for fungal chitinase (EC 3.2.1.14), which catalyses the hydrolysis of chitin to the disaccharide chitobiose (Bartnicki-Garcia, 1973). In this model, chitinase causes a limited degree of cell wall lysis so that the wall remains in a plastic and extensible condition. Significantly in this regard, chitinase activities have been detected in all actively growing chitinous fungi investigated (Gooday et al., 1986). Thus, the regulation of growth and the initiation of budding, hyphal branches and septum formation may all be dependent upon a delicate balance between wall synthesis and wall lysis.

Chitin is not found in vertebrates and the potential of chitin synthase as a target for antifungal drugs which lack host toxicity was discussed at length by Gooday (1977). Disappointingly, polyoxins, which are competitive inhibitors of chitin synthase and effective agricultural antifungal agents, have so far proved unsuitable for treatment of experimental mycoses in mammals. In view of the major morphogenetic role proposed above for chitinase, it is conceivable that this lytic enzyme presents an alternative target for antifungal compounds directed against chitin deposition.

Recently, Sakuda et al. (1987) described the inhibition of ecdysis in the silkworm Bombyx mori and the common armyworm Leucania separata by the streptomycete antibiotic allosamidin. Chitinase plays an essential role during ecdysis in insects by catalysing the hydrolysis of integumental chitin. Thus, the insecticidal properties of allosamidin may reside in its potent competitive inhibition of insect chitinase activity (Koga et al., 1987). Candida albicans is an important opportunistic fungal pathogen and chitinase activity was recently detected in this organism (Barrett-Bee \& Hamilton, 1984). In the present study, we report a detailed characterization of chitinase in a cell-free preparation from $C$. albicans and the effect of allosamidin on enzyme activity.

\section{METHODS}

Chemicals. Allosamidin was a generous gift from Dr Akira Isogai of the University of Tokyo. All other chemicals were purchased from commercial sources and were of the highest grade available. 
Organism and culture conditions. C. albicans (serotype A; NCPF 3153) was maintained on Sabouraud's dextrose agar (Oxoid) and grown in Sabouraud's dextrose broth (Oxoid) essentially as described by Hitchcock et al. (1986). Under these conditions the organisms grew exclusively in the yeast phase.

Mechanical disruption of cells. Cells were harvested by centrifugation, washed twice with distilled water and once with disruption buffer: $50 \mathrm{~mm}$-Bis-Tris, $0.25 \mathrm{M}$-sucrose, $1 \mathrm{mM}$-EDTA.Na, $\mathrm{pH} 6.5$. The organisms were resuspended in disruption buffer at a concentration of $4 \times 10^{9}$ cells $\mathrm{ml}^{-1}$ and broken in either a Braun (FRG) or a Dyno-Mill Type KDL (Willy A. Bachofen, Basle, Switzerland) disintegrator. For Braun disintegration, cell suspensions $(35 \mathrm{ml})$ were disrupted at a temperature of $4{ }^{\circ} \mathrm{C}$ using $1 \mathrm{~mm}$ diameter beads. Breakage was achieved using four $30 \mathrm{~s}$ disruption periods at 4000 r.p.m. interspersed with $30 \mathrm{~s}$ cooling periods. For Dyno-Mill disintegration, cell suspensions $(200 \mathrm{ml})$ were disrupted at a temperature of $10^{\circ} \mathrm{C}$ (maximum) in a $300 \mathrm{ml}$ batch disintegration container, using 0.75-1 mm diameter beads. Breakage was achieved using four $1 \mathrm{~min}$ disruption periods at 3000 r.p.m. interspersed with 1 min cooling periods. The temperature was maintained using an LKB Multitemp II thermostatic circulator set at $-13^{\circ} \mathrm{C}$ throughout. Homogenates were recovered by aspiration. In the buffer mixture described above Braun and Dyno-Mill disintegration procedures resulted in approximately $40 \%$ and $70 \%$ cell breakage respectively, as judged by haemocytometer counts.

Enzymic disruption of cells. Cells were harvested by centrifugation and resuspended in $0 \cdot 1 \mathrm{M}$-potassium

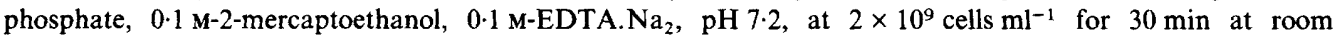
temperature. Organisms were washed twice with distilled water and twice with $0.1 \mathrm{M}$-potassium phosphate, pH 7.2, and resuspended in $0.1 \mathrm{M}$-potassium phosphate, $0.9 \mathrm{M}$-sorbitol, $10 \mathrm{~mm}$-EDTA. $\mathrm{Na}_{2}, \mathrm{pH} 7 \cdot 2$, containing Zymolyase 20T (10 units $\mathrm{ml}^{-1}$; Kirin Brewery, Japan) for $1.5 \mathrm{~h}$ at $37^{\circ} \mathrm{C}$ with gentle agitation. Spheroplasts were harvested by centrifugation at $600 \mathrm{~g}\left(r_{\mathrm{av}}, 10 \cdot 7 \mathrm{~cm}\right)$ for $5 \mathrm{~min}$, washed with $0.1 \mathrm{M}$-potassium phosphate, $0.9 \mathrm{M}$ -

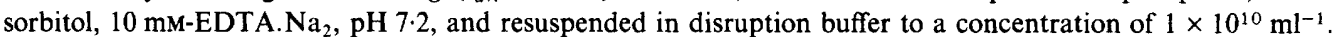
Breakage of spheroplasts was effected using 15 strokes of a hand-held Teflon-on-glass homogenizer at $4{ }^{\circ} \mathrm{C}$. The procedure resulted in approximately $100 \%$ cell breakage.

Centrifugation of the cell lysates. The cell lysates from the three breakage procedures were centrifuged at $9000 \mathrm{~g}$ $\left(r_{\text {av. }} 6.98 \mathrm{~cm}\right)$ for $20 \mathrm{~min}$ at $4{ }^{\circ} \mathrm{C}$ to remove unbroken cells and cellular debris, and the supernatants centrifuged at $145000 \mathrm{~g}\left(r_{\mathrm{av}}, 8 \cdot 1 \mathrm{~cm}\right)$ for $1 \mathrm{~h}$ at $4{ }^{\circ} \mathrm{C}$. The high speed supernatant was stored at $-20^{\circ} \mathrm{C}$ as the soluble enzyme preparation.

Extraction of chitinase using digitonin. The procedure was essentially as described by Correa et al. (1982). Briefly, $1 \mathrm{~g}$ of cells was resuspended in $5 \mathrm{ml}$ of $0.1 \%(\mathrm{w} / \mathrm{v})$ digitonin, containing $25 \mathrm{mM}-\mathrm{MES}, \mathrm{pH} 6 \cdot 3$, and $0 \cdot 1 \%(\mathrm{v} / \mathrm{v})$ mercaptoethanol. The suspension was incubated with shaking for $2 \mathrm{~h}$ at $37^{\circ} \mathrm{C}$, centrifuged for $10 \mathrm{~min}$ at $12000 \mathrm{~g}$ $\left(r_{\mathrm{av}}, 6.98 \mathrm{~cm}\right)$ and the supernatant retained.

Chitinase assay. Chitinase was assayed by the method of Molano et al. (1977) with the following modifications: chitosan ( $1 \mathrm{~g}$; Sigma) was acetylated using $1.5 \mathrm{ml}$ of acetic anhydride which contained $25 \mathrm{mCi}(925 \mathrm{MBq})$ of radioactivity (Amersham: $500 \mathrm{mCi} \mathrm{mmol}^{-1} ; 18.5 \mathrm{GBq} \mathrm{mmol}^{-1}$ ); following homogenization in a Waring blender the chitin was filtered in a Buchner funnel using Whatman no. 3 filter paper; after the chitin had been washed to neutrality it was resuspended in $300 \mathrm{ml} \mathrm{0.02 \% (w/v)} \mathrm{sodium} \mathrm{azide} \mathrm{and} 150 \mathrm{ml}$ aliquots were ball-milled in $250 \mathrm{ml}$ reagent bottles, containing thirty $5 \mathrm{~mm}$ diameter and thirty $10 \mathrm{~mm}$ diameter stainless steel balls (Bearing Service, Leeds, UK) at 120 r.p.m. for $48-72 \mathrm{~h}$; the chitin was filtered as above, resuspended to approximately $3 \mathrm{mg} \mathrm{ml}^{-1}$ in $0.02 \%$ sodium azide and stored at $4{ }^{\circ} \mathrm{C}$.

Unless otherwise stated, reaction mixtures contained $60 \mu \mathrm{l}\left[{ }^{3} \mathrm{H}\right]$ chitin $\left(2.6 \mathrm{mg} \mathrm{ml}^{-1}, 1.9 \mu \mathrm{Ci} \mathrm{mg} \mathrm{chitin}{ }^{-1}\right.$, $\left.70 \mathrm{kBq} \mathrm{mg} \mathrm{chitin}^{-1}\right), 60 \mu \mathrm{l}$ assay buffer $(0.15 \mathrm{M}$-potassium phosphate, $\mathrm{pH} 6.5)$ and $60 \mu \mathrm{l}$ diluted enzyme preparation. After incubation at $37^{\circ} \mathrm{C}$ with vigorous shaking the reaction was stopped by the addition of $0.18 \mathrm{ml}$ $10 \%(\mathrm{w} / \mathrm{v})$ trichloroacetic acid. Chitin was separated from reaction products by filtration through glass wool tightly packed into a $200 \mu \mathrm{l}$ micropipette tip. Samples $(200 \mu \mathrm{l})$ of the filtrate were mixed wth $5 \mathrm{ml}$ of LKB Optiphase Safe scintillant and radioactivity was measured in an LKB Rackbeta 1217 liquid scintillation counter. All values shown are the means of at least triplicate determinations and variation between replicates was never greater than $10 \%$.

Chitin deacetylase was assayed as described by Humphreys \& Gooday (1984). The results indicated that this enzyme made a negligible contribution to the level of labelled reaction products.

Protein concentration was determined by the method of Bradford (1976) using a bovine serum albumin standard.

\section{RESULTS AND DISCUSSION}

\section{Comparison of extraction procedures}

A number of extraction procedures were compared with the aim of isolating sufficient quantities of chitinase for future purification studies and for the characterization of potential enzyme inhibitors. High specific activities were noted for chitinase preparations isolated by 
both the Braun $\left[0.54 \pm 0.04 \mathrm{nmol}\right.$ GlcNAc formed $\mathrm{min}^{-1}$ (mg protein) $\left.{ }^{-1}\right]$ and the Dyno-Mill $\left[0.46 \pm 0.03 \mathrm{nmol}\right.$ GlcNAc $\left.\mathrm{min}^{-1}(\mathrm{mg} \text { protein })^{-1}\right]$ techniques when compared with the spheroplast breakage procedure $\left[0.08 \pm 0.01 \mathrm{nmol} \mathrm{GlcNAc} \mathrm{min}^{-1}(\mathrm{mg} \text { protein })^{-1}\right]$ (all values are the means of at least three separate preparations $\pm \mathrm{SE}$ ). However, the total activity was greater for the Dyno-Mill procedure $\left(80 \cdot 3 \pm 4 \cdot 6 \mathrm{nmol} \mathrm{Glc} \bar{N} A c\right.$ formed $\left.\min ^{-1}\left(10^{11} \text { cells }\right)^{-1}\right]$ than for the Braun $\left[52 \cdot 1 \pm 2.8 \mathrm{nmol} \mathrm{GlcNAc} \min ^{-1}\left(10^{11} \text { cells }\right)^{-1}\right]$ or spheroplast $[17.8 \pm 1.5 \mathrm{nmol}$ GlcNAc $\left.\min ^{-1}\left(10^{11} \text { cells }\right)^{-1}\right]$ techniques, reflecting the higher efficiency of cell breakage. Furthermore, the Dyno-Mill provided an ideal method for the isolation of large quantities of soluble enzyme (approximately $130 \mathrm{ml}$ per preparation) and was used for enzyme kinetic and inhibition studies.

During the conversion of Saccharomyces cerevisiae cells to protoplasts, approximately half of total yeast chitinase activity was liberated into the medium (Elango et al., 1982). The authors concluded that this portion of enzyme activity was located in the periplasmic space. In the present study, the specific and total chitinase activities extracted by the spheroplast procedure were much lower than those extracted using the Dyno-Mill or Braun homogenizers. At least part of the explanation for this observation may be that as with $S$. cerevisiae, a proportion of $C$. albicans chitinase is located in the periplasmic space and is liberated into the medium during spheroplast formation. Similarly, the high specific activity of chitinase released from cells following incubation with digitonin $\left[1.61 \pm 0.04 \mathrm{nmol} \mathrm{GlcNAc}\right.$ formed $\left.\mathrm{min}^{-1}(\mathrm{mg} \text { protein })^{-1}\right]$ may be due to preferential extraction of the periplasmic enzyme by detergent treatment. Enzyme preparations isolated using the Braun and Dyno-Mill procedures had lower specific activities than digitonin-extracted chitinase. However, the mechanical disruption procedures yielded preparations with much higher levels of total chitinase activity than those isolated using the detergent $\left[11.6 \pm 1 \cdot 1 \mathrm{nmol} \mathrm{GlcNAc}\right.$ formed $\left.\min ^{-1}(\mathrm{mg} \text { protein })^{-1}\right]$. One explanation is that the digitonin extraction procedure is inefficient. Alternatively, the proportion of total chitinase activity in the periplasmic space may be considerably lower in C. albicans than in $S$. cerevisiae. In agreement with the results of Elango et al. (1982) for $S$. cerevisiae, we were unable to detect chitinase activity in the growth medium following a $16 \mathrm{~h}$ incubation period. This suggests that export of chitinase to the periplasmic space was not followed by its release from the cell.

\section{Properties of chitinase extracted by cell homogenization}

The most sensitive assay for chitinase is a radiometric one (Cabib, 1987) and we used a modified version of the method described by Molano et al. (1977) for the studies described here. As discussed by Barrett-Bee \& Hamilton (1984), the state of sub-division of chitin particles can influence reaction velocity. In addition, we have noted that the degree of reproducibility between replicate assays is much improved following milling of the chitin to a very fine suspension using stainless steel balls. This, combined with our introduction of a modified filtration method for the separation of reaction products from chitin, has resulted in a rapid, economical, sensitive and highly reproducible assay for chitinase activity.

A plot of product formed as a function of time did not yield a straight line (Fig. $1 a$ ), in keeping with the results of Molano et al. (1977). However, a plot of the rate of reaction against enzyme concentration was linear (Fig. 1 b). Standard assay conditions were chosen where activity was on the linear portion of a progress and concentration curve. Chitin is insoluble in aqueous solutions so that it is difficult to interpret kinetic data for experiments where chitin is substrate. However, standard Michaelis-Menten kinetics were obtained and the preparation used for Fig. 1 yielded an apparent $K_{\mathrm{m}}$ of $3.9 \mathrm{mg}$ chitin $\mathrm{ml}^{-1}$ and a maximum enzyme reaction velocity $(V)$ of $2.3 \mathrm{nmol}$ $N$-acetylglucosamine formed $\mathrm{min}^{-1}(\mathrm{mg} \text { protein })^{-1}$. As noted by other workers (Barrett-Bee \& Hamilton, 1984; Humphreys \& Gooday, 1984), $K_{\mathrm{m}}$ and $V$ values differed slightly for each preparation of radioactive chitin. There has been only one previous report of chitinase activity in C. albicans (Barrett-Bee \& Hamilton, 1984). However, these workers did not quote $K_{\mathrm{m}}$ or $V$ values for their enzyme preparation. Using a radiometric assay similar to that described in the present study, Humphreys \& Gooday (1984) described $K_{\mathrm{m}}$ and $V$ values of $16.7 \mathrm{mg}$ chitin ml ${ }^{-1}$ and $2.33 \mathrm{nmol}$ diacetylchitobiose formed $\mathrm{min}^{-1}(\mathrm{mg} \text { protein })^{-1}$ respectively for their cytosolic enzyme preparation isolated from Mucor mucedo. Similarly, Correa et al. (1982) reported a $K_{\mathrm{m}}$ for chitinase from $S$. cerevisiae of $3.9 \mathrm{~mm}$, as expressed in GlcNAc equivalents. When expressed 

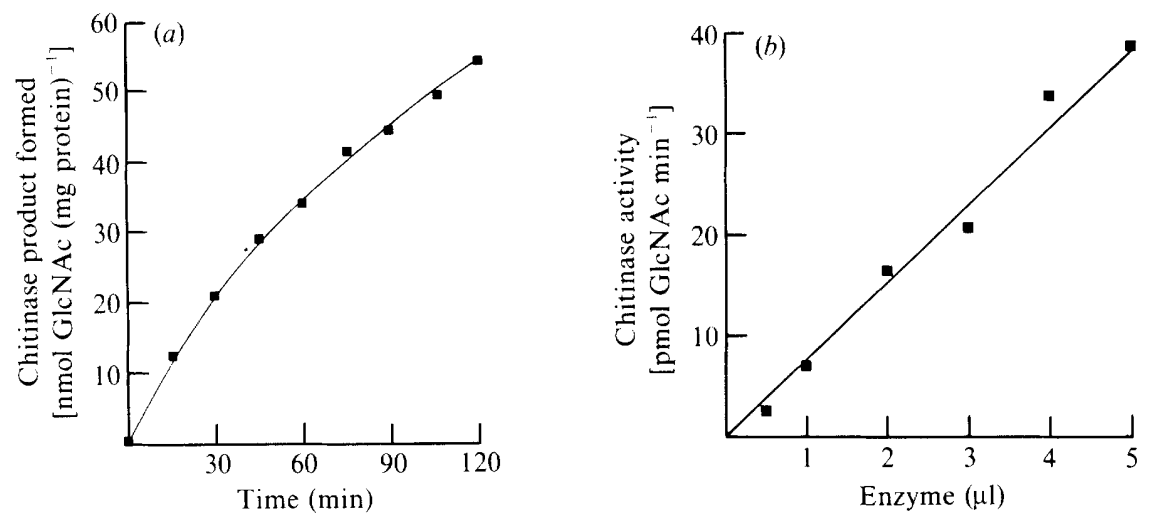

Fig. 1. Plots of product formed against time $(a)$ and enzyme activity against enzyme concentration $(b)$ for $C$. albicans chitinase.

as GlcNAc equivalents, the $K_{\mathrm{m}}$ for $C$. albicans chitinase $\left(3.9 \mathrm{mg}\right.$ chitin $\left.\mathrm{ml}^{-1}\right)$ has a value of $17.6 \mathrm{~mm}$. The $K_{\mathrm{m}}$ value for $M$. mucedo chitinase (16.7 mg chitin $\mathrm{ml}^{-1}$; Humphreys \& Gooday, 1984 ) has a value of $72.8 \mathrm{~mm}$-GlcNAc equivalents. These results indicate a marked variation in substrate affinity for the fungal chitinases studied to date.

The apparent temperature optimum for chitinase was $45^{\circ} \mathrm{C}$. However, in keeping with the studies of Barrett-Bee \& Hamilton (1984) chitinase was assayed routinely at $37^{\circ} \mathrm{C}$, the temperature of the pathogen's human host. The enzyme showed a broad $\mathrm{pH}$ dependence with an optimum around 6.5. No detectable loss of enzyme activity occurred during storage periods of three months duration at $-20^{\circ} \mathrm{C}$ or $4{ }^{\circ} \mathrm{C}$. Furthermore, the level of chitinase activity remained constant following fifteen freeze/thaw cycles over a period of two months. This extraordinary level of stability appears to be a common feature of many fungal lytic enzymes and may reflect a high level of protein glycosylation. For example, chitinase purified from $S$. cerevisiae is a glycoprotein composed of approximately $18 \%$ carbohydrate (Correa et al., 1982).

\section{Effect of allosamidin on enzyme activity}

Koga et al. (1987) reported that allosamidin inhibited Bombyx mori chitinases competitively following Lineweaver-Burk analysis of a reaction where glycol chitin was substrate. $K_{\mathrm{i}}$ values were $0.07 \mu \mathrm{M}$ and $0.11 \mu \mathrm{M}$ for chitinases isolated from the alimentary canal and larval integument of the organism respectively. These results are in close agreement with those for $C$. albicans chitinase. The inhibition of chitinase by allosamidin was dose-dependent with an $\mathrm{IC}_{50}$ value of $0.3 \mu \mathrm{M}$ (Fig. 2). Kinetic analysis of this inhibition using a variety of inhibitor concentrations is shown in Fig. 3. The data suggest that allosamidin is a potent competitive inhibitor of C. albicans chitinase with a $K_{\mathrm{i}}$ of $0.23 \mu \mathrm{M}$. There has been only one other report of the inhibition of a fungal chitinase by allosamidin. Gooday et al. (1988) reported an $\mathrm{IC}_{50}$ value of $3.2 \mu \mathrm{M}$ (using 3,4-dinitrophenyl tetra- $N$-acetylchitotetraoside as chitinase substrate) for an enzyme preparation isolated from Neurospora crassa.

Thus, our results together with those of Gooday et al. (1988) suggest that fungal chitinase is highly susceptible to inhibition by allosamidin and that the antibiotic inhibits enzyme activity in a manner similar to that described previously for insect chitinase (Koga et al., 1987). The potent inhibition of chitinase activity of the opportunistic pathogen C. albicans, coupled with the major role proposed for the enzyme in fungal growth and morphogenesis, implies that chitinase inhibition by allosamidin might be exploited to treat clinically important fungal infections. However, our preliminary studies indicate that the presence of allosamidin in the culture medium at a concentration of $30 \mu \mathrm{M}$ has no effect on cell number in cultures sampled in the late exponential phase of growth. This result would suggest either that allosamidin cannot gain access to chitinase in C. albicans or that the enzyme is not essential for growth of this organism. Humphreys \& Gooday (1984) have proposed a role for membrane-bound chitinase during 


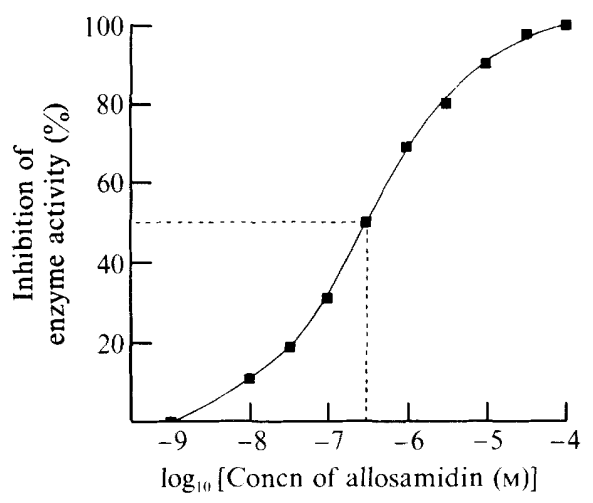

Fig. 2

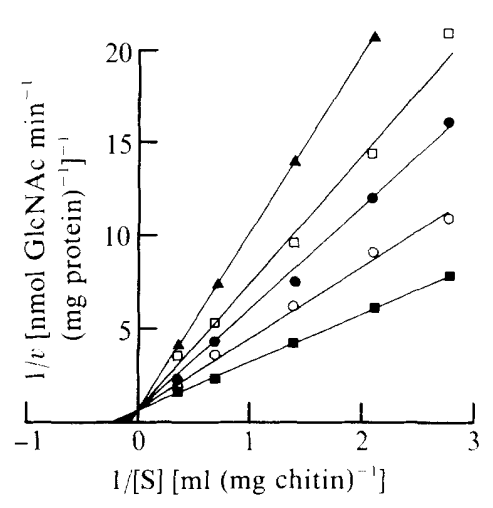

Fig. 3

Fig. 2. Effect of allosamidin on chitinase activity [ $100 \%$ activity represents $0.44 \mathrm{nmol}$ GlcNAc formed $\min ^{-1}(\mathrm{mg} \text { protein })^{-1}$.

Fig. 3. Kinetic analysis of chitinase activity in the presence of allosamidin. Allosamidin concentrations

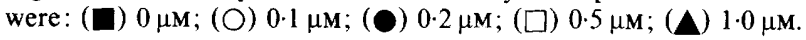

growth and morphogenesis in $M$. mucedo. If a similar role is performed by a membrane-bound chitinase in $C$. albicans then allosamidin apparently cannot gain access to the active site of this enzyme in intact organisms. Interestingly in this regard, we have recently confirmed the presence of a microsomal chitinase in $C$. albicans and work is under way to purify and characterize this enzyme.

We thank the Wellcome Trust and Beecham Pharmaceuticals for financial support, and Dr Akira Isogai for the allosamidin.

\section{REFERENCES}

BarRett-Bee, K. J. \& Hamilton, M. (1984). The detection and analysis of chitinase activity from the yeast form of Candida albicans. Journal of General Microbiology 130, 1857-1861.

BARTNICKI-GARCIA, S. (1973). Fundamental aspects of hyphal morphogenesis. In Microbial Differentiation, pp. 245-268. Edited by J. M. Ashworth \& J. E. Smith. Cambridge: Cambridge University Press.

BRADFORD, M. M. (1976). A rapid and sensitive method for the quantitation of microgram quantities of protein utilizing the principle of protein-dye binding. Analytical Biochemistry 72, 248-254.

CABIB, E. (1987). The synthesis and degradation of chitin. Advances in Enzymology 59, 59-101.

Correa, J. U., Elango, N., Polacheck, I. \& Cabib, E. (1982). Endochitinase, a mannan-associated enzyme from Saccharomyces cerevisiae. Journal of Biological Chemistry 257, 1392-1397.

Elango, N., Correa, J. U. \& Cabib, E. (1982). Secretory character of yeast chitinase. Journal of Biological Chemistry 257, 1398-1400.

Gooday, G. W. (1977). Biosynthesis of the fungal wall - mechanisms and implications. Journal of General Microbiology 99, 1-11.

GoOday, G. W. \& TrINCI, A. (1980). Wall structure and biosynthesis in fungi. Symposia of the Society for General Microbiology 30, 207-251.

Gooday, G. W., Brydon, L. J. \& Chappell, L. H. (1988). Chitinase in female Onchocerca gibsoni and its inhibition by allosamidin. Molecular and Biochemical Parasitology 29, 223-225.
Gooday, G. W., Humphreys, A. M. \& McIntosh, W. H. (1986). Roles of chitinases in fungal growth. In Chitin in Nature and Technology, pp. 83-91. Edited by R. A. A. Muzzarelli, C. Jeuniaux \& G. W. Gooday. New York: Plenum Press.

Hitchcock, C. A., Barrett-Bee, K. J. \& Russell, N. J. (1986). The lipid composition of azole-sensitive and azole-resistant strains of Candida albicans. Journal of General Microbiology 132, 2421-2431.

Humphreys, A. M. \& Gooday, G. W. (1984). Properties of chitinase activities from Mucor mucedo: evidence for a membrane-bound zymogenic form. Journal of General Microbiology 130, 1359 1366.

Koga, D., Isogai, A. Sakuda, S., Matsumoto, S., Suzuki, A., Kimmura, A. \& IdE, A. (1987). Specific inhibition of Bombyx mori chitinase by allosamidin. Agricultural and Biological Chemistry 51, 471-476.

Molano, J., Duran, A. \& Cabib, E. (1977). A rapid and sensitive assay for chitinase using tritiated chitin. Analytical Biochemistry 83, 648-656.

Sakuda, S., Isogai, A., Matsumoto, S. \& Suzuki, A. (1987). Search for microbial insect growth regulators. II. Allosamidin, a novel insect chitinase inhibitor. Journal of Antibiotics 40, 296--300.

Silverman, S. J., Sburlati, A., Slater, M. L. \& CABIB, E. (1988). Chitin synthase 2 is essential for septum formation and cell division in Saccharomyces cerevisiae. Proceedings of the National Academy of Sciences of the United States of America 83, 581-585. 